\title{
Go in Peace: Brain Death, Reasonable Accommodation and Jewish Mourning Rituals
}

\author{
Ezra Gabbay ${ }^{1} \cdot$ Joseph J. Fins ${ }^{2}$
}

Published online: 6 July 2019

(c) Springer Science+Business Media, LLC, part of Springer Nature 2019

\begin{abstract}
Religious objections to brain death are common among Orthodox Jews. These objections often lead to conflicts between families of patients who are diagnosed with brain death, and physicians and hospitals. Israel, New York and New Jersey (among other jurisdictions) include accommodation clauses in their regulations or laws regarding the determination of death by brain-death criteria. The purpose of these clauses is to allow families an opportunity to oppose or even veto (in the case of Israel and New Jersey) determinations of brain death. In New York, the extent and duration of this accommodation period are generally left to the discretion of individual institutions. Jewish tradition has embraced cultural and psychological mechanisms to help families cope with death and loss through a structured process that includes quick separation from the physical body of the dead and a gradual transition through phases of mourning (Aninut, Kriah, timely burial, Shiva, Shloshim, first year of mourning). This process is meant to help achieve closure, acceptance, support for the bereaved, commemoration, faith in the afterlife and affirmation of life for the survivors. We argue that the open-ended period of contention of brain death under the reasonable accommodation laws may undermine the deep psychological wisdom that informs the Jewish tradition. By promoting dispute and conflict, the process of inevitable separation and acceptance is delayed and the comforting rituals of mourning are deferred at the expense of the bereft family. Solutions to this problem may include separating discussions of organ donation from those concerning the diagnosis of brain death per se, allowing a period of no escalation of lifesustaining interventions rather than unilateral withdrawal of mechanical ventilation, engagement of rabbinical leaders in individual cases and policy formulations that prioritize emotional support for families.
\end{abstract}

Ezra Gabbay

ezg9002@med.cornell.edu

1 Hospital Medicine Section, Division of General Internal Medicine, Department of Medicine, Weill-Cornell Medicine, 525 East 68th Street, Box 331, New York, NY 10065, USA

2 Division of Medical Ethics, Department of Medicine, Weill-Cornell Medicine, New York, NY, USA 
Keywords Brain death · Judaism · Mourning $\cdot$ Reasonable accommodation

And Nadab and Abihu, the sons of Aaron, took each of them his censer, and put fire therein, and laid incense thereon, and offered strange fire before the LORD, which He had not commanded them.

And there came forth fire from before the LORD, and devoured them, and they died before the LORD.

Then Moses said unto Aaron: "This is it that the LORD spoke, saying: Through them that are nigh unto Me I will be sanctified, and before all the people I will be glorified." And Aaron held his peace. And Moses called Mishael and Elzaphan, the sons of Uzziel the uncle of Aaron, and said unto them: "Draw near, carry your brethren from before the sanctuary out of the camp." So they drew near, and carried them in their tunics out of the camp, as Moses had said.

And Moses said unto Aaron, and unto Eleazar and unto Ithamar, his sons: "Let not the hair of your heads go loose, neither rend your clothes, that ye die not, and that He be not wroth with all the congregation; but let your brethren, the whole house of Israel, bewail the burning which the LORD hath kindled.

Leviticus, chapter 10 verses 1-6, Machon Mamre translation.

\section{Introduction}

The story of Nadav and Avihu, sons of Aaron the High Priest who were killed by a flare of fire in Ohel Moed (the Tent of Meeting where the Divine presence resided during the Israelites' journeys in the desert), is told in the book of Leviticus. A punishment for bringing "foreign fire" into the holy space, their death is followed by a prohibition for Aaron and his remaining sons Eleazar and Ithamar to mourn them. A father who just lost his two sons "held his peace" in silence and an unceremonious removal of the dead from the community's dwelling is ordered in lieu of a funeral gathering. It is a story without closure that has left commentators struggling to explain its meaning.

The demise of the two young priests is unnatural, sudden and strange. It takes place in a mysterious environment, a place of powerful and dangerous forces. They are removed from the camp, but the text contains no mention of their burial. Thus, the final rites of death are apparently left unfinished. This liminal state between life and death, an enormous, yet ill-defined loss, has parallels in the experience of modern families who struggle with a diagnosis of brain death in a loved one.

Determination of death by brain death criteria can be made when whole brain death occurs. This is characterized by complete and irreversible cessation of all brain function, manifested by an eyes-closed state of unresponsiveness, absence of reflexes that normally indicate brain-stem function and cessation of spontaneous breathing (apnea). Since the heart continues beating and many of the functions of cells and tissues are maintained, brain death is confusing and difficult to accept. The enigmatic Iron Age tale of the sons of Aaron's death in a desert tent and the ostensibly scientific, high-tech, modern story of brain death in an intensive care unit seem to echo each other across the millennia that separate them. 
In this article, we look at the complex history that Ultra-Orthodox Judaism has had with brain death. We consider the scientific, clinical, social and religious intricacies related to brain death determinations in Ultra-Orthodox Jewish patients. We also examine legislation passed in the USA and Israel, intended to accommodate religious objections to brain death. These accommodations, which often result in a period of uncertainty, confusion and distress, may paradoxically undermine the healing effect of Jewish traditions that are meant to support the bereaved. These practices include rapid separation of the family from the physical body of the dead and a structured, predictable process of mourning. Finally, we propose some potential ways in which brain death disputes between Orthodox Jewish families and medical staff can be mediated through a pastoral approach that promotes healing rather than a competition between rigid scientific and theological narratives of death.

\section{A Brief History of Brain Death}

The concept of brain death was first introduced in the 1960s. The Harvard professors who wrote the Beecher report in 1968 (Beecher et al. 1968) introduced the idea that irreversible coma with complete neurological devastation, which includes loss of brain-stem function, is tantamount to death. Under this definition, death can be determined even if certain cardiac and peripheral autonomic neurological mechanisms preserve contractions of the heart such that the brain-dead person has a pulse, a blood pressure and warm skin. This concept was born as an attempt to grapple with momentous changes in medical care rather than as a by-product of evidencebased medicine. ${ }^{1}$ The technological innovation of mechanical ventilation now allows for cardiac survival even in the absence of any respiratory drive, transforming what had previously been a concerted collapse of vital functions into a fragmented process that could delay the final determination of death. Utilitarian considerations such as freeing up hospital beds taken up by patients devastated by neurological damage and the potential for procuring organs for transplantation were additional considerations included in the Harvard Committee's report. Standards for the determination of brain death have remained fairly constant since the Harvard Committee's definition, although the original parameters have been somewhat refined over the years. Some of the current diagnostic criteria for brain death include: irreversible and proximate cause of coma, lack of all evidence of responsiveness to pain or other stimuli, absence of brain-stem reflexes (e.g., lack of pupil constriction when light is shed into the eye) and absence of a breathing drive (Wijdicks et al. 2010).

In certain circumstances, additional tests that check for electrical activity or blood flow in the brain (such as electroencephalogram and cerebral angiography, respectively) may sometimes be used, although these are not without risks of false positive results. These and other ancillary tests are employed when there is uncertainty about the reliability of parts of the neurologic examination. They can also be used in circumstances where the apnea test (when doctors take a person who they believe

\footnotetext{
1 The only reference in the original Beecher committee's report is to a sermon by Pope Pius the 12 th. No data from animal or human studies were cited.
} 
is brain dead off the ventilator to make sure he or she is not breathing on their own) cannot be performed (Wijdicks et al. 2010).

A diagnosis of brain death is often followed by either discontinuation of mechanical ventilation and other medical interventions, and the subsequent cessation of heart function (cardiac death), or by surgery to procure organs for transplantation.

Resistance to the concept of brain death has persisted in the decades that followed its original introduction for reasons that extend far beyond questions of scientific validity. At the same time, its integration into clinical practice has resulted in significant benefits to humanity, most notably, organ transplantation from brain-dead donors (Aviv 2018).

Disputes over the determination of brain death are among the most contentious and painful issues that arise between families of neurologically devastated patients and medical professionals. The patient is, by definition, unable to directly participate in the conversation except by advance directives and the family's account of his or her prior wishes and values. The factors that inform these disputes are multidimensional, and include the counterintuitive nature of brain death (Schiff and Fins 2016) (how can a person be dead if they are warm, have a pulse, their chest moves in what looks like breathing?). There are also emotional, social (mistrust of the medical establishment among minorities and marginalized groups) and religious elements that constitute objection to brain death determinations in many cases (Johnson 2016; Racine 2015; Segal 2014). Objections to brain death can be found among people of all religious and ethnic groups. African-Americans, for example, may object on both religious and social grounds, the latter related to historically justifiable mistrust of the medical system, and many people in Japan, some Afro-Caribbeans and Native Americans may have religiously or socially based objections as well (Fins 1998; Morioka 2001; Olick et al. 2009). Orthodox Jews, however, have come to be more strongly identified with objections to brain death than perhaps any other group.

\section{Orthodox Judaism and Brain Death}

The Orthodox Jewish approach to brain death is rooted in Halachah, the legal framework for the practical code of religious observance. Halachah, based on interpretation of the laws of the Hebrew Bible, comprises much of the vast corpus of rabbinic literature from antiquity to modernity. It encompasses all aspects of human life, including (but certainly not limited to) diet, work, marriage, sex, prayer, ritual, business and medicine.

The Halachic system of deduction employs the very methods of scientific and legal reasoning that the medical and legislative establishments use to define and implement the concept death by neurologic criteria. There is quite a bit of homology in the patterns of analysis used by both sides of the debate, even if their conclusions are in some cases quite different. 
One common example of legalistic-scientific Halachic thinking in contemporary rabbinic disputes over brain death relates to a passage in the Talmud in which a man is found buried under a pile of rocks on the Sabbath. ${ }^{2}$ The sages in antiquity allowed passers-by to clear the stones (something that is ordinarily considered work and thus prohibited on the Sabbath) until they reach the buried man's nose. If they find him to be breathing, they may (and indeed must) continue clearing the rubble and extricate the man completely. If, however, no breathing is detected (analogous to an apnea test) - then according to some opinions they must leave him be and may not continue to violate the Sabbath, for the man is already dead. A second opinion in the Talmud does require digging further to uncover the heart and ascertain lack of pulsation before determining death.

This scenario of an imagined man in the rubble has become, by way of analogy, the basis for rabbis' thinking about brain death. Proponents of accepting braindeath diagnoses see the first opinion (uncover the nose and stop digging if there is no breath detected) as accepting of brain death because it implies that someone who is not breathing is dead, and therefore, there is no need to continue digging to uncover the chest to ascertain whether the heart is beating or not (Reifman 2011). Opponents of accepting brain death as a valid diagnosis rely on the second opinion, which implies the need to determine cardiac death, rather than relying on apnea alone, before forgoing further efforts to extract the trapped man.

Some Orthodox rabbinic leaders (such as Rabbi Dr. Moshe Tendler, Rabbi Professor Avraham Steinberg, Rabbi Ovadia Yosef and the Chief Rabbinate of Israel) have considered brain death to be potentially Halachically acceptable in certain circumstances. Efforts to convince rabbis of the validity of brain death included an experiment performed in Israel in which a decapitated sheep' ${ }^{3}$ heartbeat could be sustained to undergo a delivery of a lamb by way of cesarean section (Steinberg and Hersch 1995). Other prominent rabbinic figures (most notably Israeli rabbis Yoseph Shalom Eliashiv, Shlomo Zalman Auerbach and Eliezer Waldenberg) strongly opposed brain-death criteria for the purposes of organ procurement. One particularly interesting view is that attributed to Rabbi Hershel Schachter, who categorized brain-dead people as "safeik chai, safeik met"(in a state of doubt as to whether one is alive or dead). As such, removal of organs would be prohibited as potential murder, but in other respects the person would be treated as dead. For example, a Cohen (a person of priestly descent) would not be allowed to enter the patient's room, so as to avoid the ritual impurity imparted by the dead (Tum'at Metim) (Breitowitz 1996). This distinction might also clarify some of the uncertainty around the position of Rabbi Moshe Feinstein, one of the leading figures in the history American Orthodox Jewry. Some have argued that Rabbi Feinstein's approval of the absence of brain activity on radionuclide brain scanning (a scan of the head using a radioactive material to detect blood flow in the brain), as a valid determination of death, implies that he viewed brain death as Halachically acceptable. Others have cited his argument that harvesting organs from patients before cardiac death was tantamount to murder (Breitowitz 1996).

\footnotetext{
2 Babylonian Talmud, Tractate Yoma 85a.

${ }^{3}$ Decapitation is accepted by certain rabbis as indisputable evidence of death.
} 
This discrepancy can be explained, in part, by understanding that the fundamental nature of rabbinic reasoning is legal, not metaphysical. The uncertainty around the same person's life or death status may be that he or she is "dead enough" to be concerned about ritual impurity but not dead enough to remove vital organs. The question of the precise state of life or death is secondary to legal questions of permissibility or prohibition of particular actions.

Similarly, Rabbi Ovadia Yosef, the foremost Sephardic rabbinic leader in recent generations, accepted whole brain death accompanied by apnea as Halachically acceptable death, but made his acceptance contingent on securing the rights of those patients and families who choose to refuse organ donation or discontinuation of life support measures. Interestingly, his ruling contains neither an explicit prohibition against organ donation nor one against termination of life-sustaining treatment if the family or patient's prior wishes allow these actions. In fact, Rabbi Steinberg reports that Rabbi Yosef permitted organ donation in at least one case of a young woman confirmed as brain dead by clinical criteria and trans-cranial Doppler (an ultrasound test that can measure blood flow in the brain) (Steinberg 2010).

Overall, however, opponents of brain death seem to be the more influential and dominant school of thought among Ultra-Orthodox Jews in Israel, the USA, Canada and other countries. In light of this plurality, the acceptance of brain death in Orthodox circles tends to adopt a more low-key and defensive stance in the debate. Nonetheless, though the Halachic debate over the validity of brain death is far from over, large portions of the Orthodox and ultra-Orthodox communities remain stronglyand vocally_ - opposed to brain-death determinations.

\section{Representative Cases}

One prominent recent case that illustrated the strength of objection to brain death was that of Shalom Ouanounou, a 25-year-old Orthodox Jewish Canadian man, who was diagnosed with brain death in September 2017 as a complication of a severe asthma attack followed by catastrophic anoxic brain injury (brain damage as a result of lack of oxygen). His family appealed to an Ontario court arguing that stopping life-sustaining treatment such as mechanical ventilation and providing feeding through a tube would violate his charter right to religious liberty and asked that a preexisting death certificate be revoked. In November 2017, the family won an injunction to keep these treatments going, while the court deliberated. Mr. Ouanounou's heart subsequently stopped beating in March 2018. It was only then, 6 months after the diagnosis of brain death, that his family accepted his death and held his funeral service. There, family, friends and community leaders eulogized him and spoke of the meaning of his life and death from a personal, community and religious perspective.

Mr. Ouanounou's case remained active in the Ontario Superior Court even after his death, until a decision in November 2018 that declared it moot. This decision was based on the fact that a similar case, that of Ontarian Tasha McKitty, was already decided 5 months earlier. Ms. McKitty was a 27-year-old woman who was declared 
brain dead and whose parents were seeking an order to keep her on mechanical ventilation, arguing that according to her Christian faith she is alive as long as her heart is beating.

Since the court rejected the plea of the McKitty family in June 2018, the Ouanounou's family's case was considered moot by the time of the court's ultimate decision (Blackwell 2017; Lungen 2018; McGillivray 2018; Rieti 2018).

In Israel, the death in 2010 of Avi Cohen, a nationally renowned soccer player, illustrated the powerful effect of religious sentiments against brain death in a very publically apparent way. Mr. Cohen, who was diagnosed as brain dead after a motorcycle accident, had signed an organ donor card. His family initially agreed to organ donation but shortly thereafter rescinded their consent after pressure from UltraOrthodox rabbis who opposed brain death and influenced the family to change their position (Ettinger and Even 2010).

\section{Legal Efforts at Resolution and Accommodation}

Legal efforts to address religious objections to brain death have been undertaken in both the USA and Israel.

In the USA, efforts can be traced back to the Uniform Determination of Death Act of 1981, a model state law that allows for determination of death based on "irreversible cessation of all functions of the entire brain, including the brain stem," which has been adopted by most states. Four states: California, Illinois, New York and New Jersey, introduced some degree of accommodation of religious and/or moral objections into their legislative or regulatory schema pertaining to brain death.

The nature and extent of accommodation span a spectrum from vague, general recommendations to more binding provisions. In Illinois, the law calls for hospitals to "allow health care professionals, in documenting a patient's time of death at the hospital, to take into account the patient's religious beliefs concerning the patient's time of death" (210 ILCS 85/6.23). In California, the law stipulates that hospitals have policies to give families who object to brain death "a reasonably brief period" defined as "an amount of time afforded to gather family or next of kin at the patient's bedside." (Cal. HSC. Code 1254.4).

New York and New Jersey have adopted legislation or regulation widely perceived to be the most far-reaching in their accommodation of religious or moral objections to brain death (Johnson 2016).

In New York, State Guidelines for Determining Brain Death stipulate that: "Hospitals must establish written procedures for the reasonable accommodation of the individual's religious or moral objections to use of the brain death standard to determine death when such an objection has been expressed by the patient prior to the loss of decision-making capacity, or by the surrogate decision-maker. Policies may include specific accommodations, such as the continuation of artificial respiration under certain circumstances, as well as guidance on limits to the duration of the accommodation" (New York State Department of Health \& New York Task Force on Life and the Law 2011) The duration of such accommodations is not specified. Notably, the process of reasonable accommodation only begins after 
the determination of brain death. While families must be notified of an impending brain-death determination, they cannot refuse the testing under New York law. The period of accommodation begins after the determination of death, and surrogates cannot prevent the removal of the ventilator after the accommodation has ceased.

The New York City Health and Hospitals Corporation Ethics Network specifically states that such accommodations are short in duration and do not imply "that the now dead individual must continue to be treated as a patient" (Network.); however, there is no state-wide consensus on this point and there is variability in practice patterns.

New Jersey Law, on the other hand, does allow families de-facto veto power over the determination of death by neurological criteria. In the case of a religious objection (but not a conscientious non-religious one) "(death) shall be declared and the time of death fixed, solely upon the cardio-respiratory criteria "(NJ L.1991, c.90, s.5 26:6A-5). Insurance providers are also prohibited from denying coverage on the basis of a brain-death determination in New Jersey (Johnson 2016).

In Israel, religious objection to brain death is common, despite a 1986 decree by the Chief Rabbinate accepting brain death. ${ }^{4}$ These objections were associated with a low rate of organ procurement for transplantation. In an effort to reconcile the medical profession's stand on brain death and the religious community's objections to it, Israeli legislators passed the Brain-Respiratory Death Act. ${ }^{5}$ The law has a number of provisions. First, it requires clinicians to actively elicit the patient's prior views regarding brain death and hear the family's position rather than simply inform the family of an intent to perform brain-death testing. Secondary, mandatory apnea testing is required. Ancillary testing cannot be substituted if an apnea test is technically impossible. When an apnea test cannot be performed, for example when there is an injury to the skull or face or when there is very unstable blood pressure, a determination of death by brain death cannot be declared. Finally, ancillary testing is mandatory, even when apnea test and other clinical exam criteria are met. While this requirement was intended to impose more rigor onto the process, it has resulted in a false negative rate for brain-death determinations, i.e., an inability to determine brain death where clinical findings are otherwise compatible with the diagnosis, in $22 \%$ of cases in one cohort that was studied (13 of 60 patients in 2010). This confounder, family objections to brain-death testing and cases of inability to perform an apnea test or secure ancillary testing have greatly complicated the process of brain death determination in Israel (Cohen et al. 2012)

\footnotetext{
${ }^{4}$ Many ultra-Orthodox Jews in Israel view the official, State-run rabbinate, which is part of a secular political and Civil-Service system, with some reservation. Its rulings are generally thought to carry less weight than those of independent "poskim" rabbis and heads of Yeshivas whose authority is based on personal reputation based on a lifetime of Torah study, such as rabbis Elyashiv, Auerbach and Feinstein mentioned above (Friedman 2015).

5 The name of the law emphasized the apnea component of brain-death determination, in an effort to appeal to rabbinic leaders. This is because apnea is an important part of Halachic determination of death, regardless of whether brain-death criteria are accepted or whether only cardiac arrest and apnea are used to determine death.
} 


\section{Unintended Consequences of Accommodations and the Jewish Philosophy of Mourning and Death}

While the intention behind accommodation was to address religious concerns about brain death, there are unintended consequences which potentially create an openended period in which the person, whose status is debated, is maintained on "lifesustaining" treatments (most notably mechanical ventilation). The consequence of this is that the final rites of death are postponed, preventing the balm of the mourning process from comforting the bereaved, or soon to be bereaved family. This interim phase has significant religious, spiritual and emotional consequences.

There is a classic Jewish joke that encapsulates this dilemma. It tells of an elderly man on his deathbed at home. He suddenly notices the delightful smell of brownies wafting from the kitchen oven. "Could I have a brownie?" he asks his family, hoping to enjoy one last treat before he dies. "No!" comes the stern reply, "we're saving them for Shiv'a." This story of delayed Shiv'a-the communal rituals of Jewish mourning which occur in the week following death-is not only a humorous, possibly stereotypical, depiction of intense family dynamics, but also speaks to the centrality of ritual and tradition in how Jews deal with death.

Judaism approaches death and grief — as it does everything else-with rules and codes of behavior, creating a constructive dialog between emotion and action (Bloch et al. 2018). By defining one's reaction to pain and loss in the language of ritual and observance, one can confront the reality of death and work through sorrow and anger in a tangible, concrete way (Gordon). There is a highly prescribed sequence of observances to help the family and community respond to loss. These are postponed when brain-death accommodations delay the acceptance of an inevitable death.

These rituals include a period of preparation for the funeral by the family of the deceased (Aninut), and producing a tear in one's clothes as a symbol of the breech that occurred in one's life with the loss of a loved one (Kriah). Specially trained members of the burial guild (Hevra Kadisha, the Holy Burial Society) are charged with purifying the body, a process cloaked in some mystique and trepidation. These relate to the laws pertaining to the impurity of corpses (tum'at metim), which means avoidance of unnecessary physical contact with the dead body, as well as the need to clean and handle the corpse in a respectful and dignified way "kevod hamet."

Preparation of the corpse is followed by a timely burial. Of note, in the context of delays incurred in the declaration of death by religious accommodation, there are Halachic prohibitions against delays in burial. These are believed to represent disrespect for the dead. The funeral ceremony includes a prayer in which the mourners accept God's judgment regarding life and death as true and just (tziduk hadin). In some communities (such as among Ashkenazim in Jerusalem), members of the burial society address the deceased at the graveside and ask for forgiveness for errors inadvertently committed in handling the corpse. They then bid the departed to "Go in Peace."

The funeral is followed by a structured and staged process of grief, with different rules and customs for the first week (shiv'a), the first month (shloshim), the first year and beyond (Lamm 2000). The symbolic meaning of these laws amounts to a 
twofold psychological process: quick separation from the physical body of the dead followed by a slow process of transition from the presence of the deceased person to the legacy of their hallowed memory. The process is one of closure, acceptance, commemoration, faith in the afterlife and affirmation of life for the survivors.

The period of contention of brain death under the reasonable accommodation laws interrupts this scripted process. As such, it undermines the deep psychological wisdom that lies at the foundation of these Jewish traditions. Instead of acceptance, there is an incentive to resist the diagnosis of death. Instead of separation, there is lingering, agonizing presence with what even according to some Ultra-Orthodox rabbis might be a dead corpse (as detailed in the discussion of "safeik hai safeik $m e t$ " above). Rather than quiet, dignified reflection on the deceased person's life, there is petty bargaining and conflict. And perhaps most significantly, instead of traditional support from family and community in the process of grieving, there is recruitment of advocates for and against the delay, leading to an atmosphere of strife and anger between the family and the medical staff.

Often the family is torn between those members advocating more forceful resistance and those who wish to end the painful process rather than protract it. This undermines "Shlom Bayit," peace in the home, and disrupts the family, which is the cornerstone of Jewish life.

Perhaps the most fundamental way in which this ill-defined state is at odds with an Orthodox Jewish worldview is that it violates the rabbinic philosophy that seeks to understand the world through concrete binary categories of law. Actions are either permitted or forbidden, things are either pure or impure and individuals are either culpable or exempt. Brain death defies such clear definitions, and as such, for many Orthodox Jews it is a liminal and conceptually confusing - a state that represents a loss without a name. Families are not only deprived of solace during this period of contention, but may also carry the burden of internal tension in an enduring complicated bereavement. Such tensions can progress to fractures within families, especially when different family members disagree about the validity of brain death and with the recommendations of the medical staff.

\section{Clinical Responses During Accommodation}

From the providers' perspective, this period represents one of enormous stress. They are unable to help their former patient who is now considered dead by accepted biomedical standards, but they are also limited in their ability to provide support for the family, with whom they are now in a potentially contentious situation. The undoing of the therapeutic alliance in these circumstances deprives the provision of medical care of its essential meaning and can contribute to frustration and burnout.

What then are some potential solutions to this predicament? One potential approach might be to do away with reasonable accommodation clauses and policies, and present families with brain death as a "fait accompli." One might argue that doing away with a prolonged period of negotiation and contention may benefit the family by removing the burden of contested medical decisions. This would bring 
needed closure, remove guilt and allow the tradition to provide ancient rites of comfort. When the decision is decreed by outside forces, there is nothing to be done.

But disempowering families and forcing them to abandon their convictions might be counter-productive. Moreover, legislative changes are often crude instruments that fail to address the fine complexities of moral and philosophical disputes. While laws and regulations that recognize accommodation are far from perfect, they do represent an evolution in the medical profession's understanding that even 50 years after its introduction, the concept of brain death remains difficult for many to accept. The compromises offered in these laws, however problematic, comprise an admission that unilateral assertion of professional power is unlikely to promote an ethically sound and sustainable physician-patient relationship.

There are several ways in which clinicians can adjust their approach to braindeath disputes within the context of existing reasonable accommodation laws and regulations and preserve and affirm fiduciary obligations

First, physicians, nurses and other providers need to take time to listen to the family's perspective and explore what has previously been described as "an intermediate normative step between describing this biological state" (of brain death) and "making decisions for those individuals who find themselves in it" (Fins 1995). This measured approach is particularly important in the face of institutional pressures to reach a timely resolution and manage resources efficiently, which can lead to impatience with families' resistance to accept brain death.

Accounts by Ultra-Orthodox advocacy groups tell stories of families who felt hurried and anxious about potential unilateral action by medical institutions (Chayim Aruchim 2015). When families, rabbis or advocacy groups react to pressure by turning to hospital leadership or resorting to litigation, an adversarial, contentious relationship often supplants the previous therapeutic alliance. It is also potentially counter-productive as these disputes can prolong the time course to a potential resolution.

Second, physicians should avoid attempts to frame the conversation with families who reject brain death within a secular binary "dead or alive" perspective. Instead, they should reframe the patient's status within a theocentric paradigm drawing upon two conflicting binaries in Halachic law (Fins 1995). In this way, the discussion should include both the recognition of the sanctity of life in Orthodox Jewish thought and understanding of the limits of medical interventions at the end of life. The concept of Goses, a concept akin to medical futility describing a person who is at the advanced stages of the dying process, is a useful one in this context.

Some rabbinic authorities stress the need to allow people in the state of Goses to peacefully and comfortably pass rather than employ disproportionate aggressive medical interventions with little or no prospects of meaningful benefit. Rabbinic sources that could be seen as supporting this notion include the story of Rabbi Yehudah Ha-Nasi's maidservant who, seeing his suffering at the time of his dying, threw a clay jug from the roof to the ground as sages were incessantly praying to keep him alive. The sudden noise distracted the sages who fell silent for moment and with that hiatus in prayer the rabbi quickly died. ${ }^{6}$ Another source comes from Rabbi

\footnotetext{
${ }^{6}$ (Babylonian Talmud, tractate Ketubot 104a).
} 
Moshe Isserles. In his commentary on the Shulchan Aruch he states (relying on Sefer Hasidim) that a woodchopper who makes noise outside the house of a Goses may be asked to leave (Klapper 2017). This implies that obstacles to an impending death of a hopelessly ill patient may be removed in certain circumstances. Considering the brain-dead person as Goses, rather than insisting on the family's acceptance of that person as wholly dead, holds the potential of drawing upon Halacha itself to find common ground between medical and religious goals (Fins 1995; Gabbay et al. 2017).

Third, individual clinicians and the medical system as a whole need to more clearly separate the determination of brain death per se from requests for organ donation. This distinction can help avoid the perception of potential dual interests, which can undermine family trust that clinicians are working in the patient or family's best interest. Suspicion that doctors have ulterior motives, or are merely insensitive to the sanctity of human life, ${ }^{7}$ may complicate the relationship further and must be addressed.

Beyond this potential for a conflict of interest, organ donation becomes problematic under Orthodox interpretations of Jewish law. Even some rabbis who are inclined to accept brain death may recoil from accepting organ harvesting from brain-dead patients as Halachically permissible. Assurance that a medical diagnosis of brain death does not mean carte blanche for organ harvesting may help to refocus the conversation on the patient and lead to shared decision making with surrogates.

Fourth, hospitals should consider a policy of no escalation of treatment rather than immediately insist on active withdrawal of mechanical ventilation and cardiovascular support, at least for the initial period after confirmed or suspected brain death. Notwithstanding outlier cases, most brain-death patients will usually sustain a cardiac arrest within days, even if maintained on mechanical ventilation. A study of outcomes in comatose patients found that in a subset of 73 patients who met brain-death criteria, all patients developed cardiac asystole, and in $97 \%$ percent of cases, cardiac death occurred within 1 week of meeting brain-death criteria despite continued full cardio-respiratory support (Hung and Chen 1995). More recent studies, perhaps reflecting advances in intensive care support, show a median of 6 days and mean of 8.2 days from brain death to cardiac death (Al-Shammri et al. 2003). Another study showed the median and mean somatic survivals of brain-dead patients of 3 and 4.5 days, respectively (George et al. 2016).

Thus, in many cases, the period usually taken up by efforts at resolving disputes might equally be managed by a more pacific approach in which the medical team patiently waits for cardiac death to follow death by neurologic criteria. The goal is to help alleviate the family's distress and help the patient's loved ones realistically recalibrate their expectations. This should motivate clinical responses, rather than

\footnotetext{
7 Rabbi Moshe Feinstein, for example, in his commentary on Numbers 35, 33 holds that secular prohibitions against bloodshed are driven by practical concerns about maintaining social order (Yishuv-haOlam) and are therefore contingent on circumstances, as opposed to the Torah's reasoning for prohibiting murder that is absolute and based on the inherent value of human life. He incidentally notes in the original Hebrew version of the same passage, that "it is well known that doctors do not try very hard on behalf of an elderly patient." (Dorosh Moshe, Parashat Masei).
} 
securing an immediate declaration of brain death. To that end, we suggest two key provisions that should accompany such an approach of watchful waiting. First is the avoidance of cardiopulmonary resuscitation, escalation of vasopressor support (medications that help keep blood pressure from being dangerously low) to maintain hemodynamics, and the initiation of dialysis and other "life-sustaining" measures (if that term can even be used in this setting). Second, we recommend a pre-defined time point for re-evaluation and re-negotiation with families when cardiac function persists beyond an initial period of several days.

Fifth, we highly recommend establishing a functional, mutually respectful and constructive relationship between medical professionals and rabbinic leaders. This is essential for any meaningful process of engaging the Ultra-Orthodox community. While, as noted above, some rabbinic leaders are entirely uncompromising in their opposition to brain death, others who may follow the approach of Rabbis Yosef and Tendler may support a compromise approach. Taking organ donation off the table, when appropriate, and deferring discussion of withdrawal of ventilatory support in the initial stages of the dialogue may facilitate these discussions and help foster an alliance. This is essential given the centrality of rabbinic authority in these communities. Rabbis, community organizations and advocacy groups can also facilitate the transfer of patients to facilities affiliated with the Ultra-Orthodox community that may assume care of these patients, thereby neutralizing tensions.

In sum, when addressing brain death objections from Orthodox Jewish families, empathy and support for families in this predicament is essential. Orthodox Judaism seeks meaning through action and fulfillment of moral duty. Families stranded in a no-man's-land of devastating loss with neither hope for meaningful recovery nor closure are deprived of the redeeming power of mourning rituals prescribed by Halachah. To remediate this situation, we recommend efforts to move from the confines of a secular-theological debate (Fins 1995) and on toward the invocation of a pastoral-spiritual ethos. This will better serve families and help doctors, nurses, chaplains and social workers work through the crisis (Brenner et al. 2005). They too require an opportunity to process this traumatic experience and recover from it.

\section{Lessons Learned: Moving Beyond the Debate}

The story of Nadav and Avihu reappears in Leviticus several chapters after it is first told. There, God speaks to Moses and through him provides precautions for Aaron, the bereaved father. God's intent is for people to learn from the tragedy of paternal loss and to prevent future disasters by providing instructions on how to safely approach the Holy Presence. He prescribes the performance of elaborate rituals of purification and the bringing of sacrificial offerings.

The Biblical lesson is that we can learn from tragedy and loss. We can and must change our practices to move forward. As practitioners who have witnessed the tragedy of loss, exacerbated by disputes over brain death determinations, we hope our recommendations for accommodation and mediation can lessen the burden for those 
who follow. If so, they will serve as a benediction to those patients and families whose loss and suffering still linger in our memory.

Acknowledgements We would like to thank Dr. Arthur T. Evans for his ongoing support of our collaborative work. Parts of this work were presented as oral presentations in the 2018 UNESCO Chair of Bioethics Conference in Jerusalem, Israel, and the 2018 American Society of Bioethics and Humanities Annual Meeting in Anaheim, CA.

\section{Compliance with Ethical Standards}

Conflict of interest The authors declare that they have no conflict of interest.

Ethical Approval This article does not contain any studies with human participants or animals performed by any of the authors.

\section{References}

Al-Shammri, S., Nelson, R. F., Madavan, R., Subramaniam, T. A., \& Swaminathan, T. R. (2003). Survival of cardiac function after brain death in patients in Kuwait. European Neurology, 49(2), 90-93. https://doi.org/10.1159/000068506.

Aviv, R. (2018). What does it mean to die? The New Yorker. Retrieved from https://www.newyorker.com/ magazine/2018/02/05/what-does-it-mean-to-die.

Beecher, H. K., Adams, R. D., Barger, C. A., Curran, W. J., Denney-Brown, D., Farnsworth, D. L., et al. (1968). A definition of irreversible coma. Report of the Ad Hoc Committee of the Harvard Medical School to Examine the Definition of Brain Death. JAMA, 205(6), 337-340.

Blackwell, T. (2017). Orthodox Jewish family wants brain dead son's death certificate rescinded because faith won't accept he's deceased. National Post. Retrieved from https://nationalpost.com/news/toron to/orthodox-jewish-family-asks-court-to-rescind-brain-dead-sons-death-certificate-because-faith -wont-accept-hes-deceased.

Bloch, A. M., Gabbay, E., Knowlton, S. F., \& Fins, J. J. (2018). Psychiatry, cultural competency, and the care of ultra-orthodox Jews: Achieving secular and theocentric convergence through introspection. Journal of Religion and Health, 57(5), 1702-1716. https://doi.org/10.1007/s10943-018-0678-z.

Breitowitz, Y. A. (1996). The brain death controversy in Jewish law. Jewish Action, 5752, 63-66.

Brenner, D., Blanchard, T., Fins, J. J., \& Hirschfield, B. (2005). Embracing life and facing death, a Jewish guide to palliative care. CLAL-The National Jewish Center for Learning and Leadership: Springer.

Chayim Aruchim. (2015). Chayim Aruchim hailed as dedicated advocate for patients' rights. Retrieved from http://www.chayimaruchim.com/News/Chayim-Aruchim-Hailed-as-Dedicated-Advocate-forPatients-Rights/p-123-105/.

Cohen, J., Ashkenazi, T., Katvan, E., \& Singer, P. (2012). Brain death determination in Israel: The first two years experience following changes to the brain death law-opportunities and challenges. American Journal of Transplantation, 12(9), 2514-2518. https://doi.org/10.1111/j.1600-6143.2012.04089 .X.

Ettinger, Y., \& Even, D. (2010). Despite donor card, soccer star Avi Cohen's family keeps hospital from taking organs after lobbying by rabbis. Ha'Aretz Retrieved from https://www.haaretz.com/1.51010 32.

Fins, J. J. (1995). Across the divide: Religious objections to brain death. Journal of Religion and Health, 34(1), 33-39.

Fins, J. J. (1998). Approximation and negotiation: Clinical pragmatism and difference. Cambridge Quarterly of Healthcare Ethics, 7(1), 68-76.

Friedman, S. (2015). The end of the chief Rabbinate? Ha'Aretz. Retrieved from https://www.haaretz.com/ opinion/.premium-the-end-of-the-chief-rabbinate-1.5386174, 
Gabbay, E., McCarthy, M. W., \& Fins, J. J. (2017). The care of the ultra-orthodox Jewish patient. Journal of Religion and Health, 56(2), 545-560. https://doi.org/10.1007/s10943-017-0356-6.

George, S., Thomas, M., Ibrahim, W. H., Abdussalam, A., Chandra, P., Ali, H. S., et al. (2016). Somatic survival and organ donation among brain-dead patients in the state of Qatar. BMC Neurology, 16(1), 207. https://doi.org/10.1186/s12883-016-0719-8.

Gordon, A. A psychological interpretation of the laws of mourning. Retrieved from https://www.myjew ishlearning.com/article/a-psychological-interpretation-of-the-laws-of-mourning/.

Hung, T. P., \& Chen, S. T. (1995). Prognosis of deeply comatose patients on ventilators. Journal of Neurology, Neurosurgery and Psychiatry, 58(1), 75-80.

Johnson, L. S. (2016). The case for reasonable accommodation of conscientious objections to declarations of brain death. Journal of Bioethical Inquiry, 13(1), 105-115. https://doi.org/10.1007/s1167 3-015-9683-z.

Klapper, A. (2017). End of life issues part three: Of woodchoppers and flickering flames. Retrieved from http://www.torahleadership.org/categories/flamechopperenlife3_2meks.pdf.

Lamm, M. (2000). The Jewish way in death and mourning (Rev ed.). Middle Village, NY: Jonathan David Publishers.

Lungen, P. (2018). Netanel Ouanounou dies after six months on life support. Canadian Jewish News. Retrieved from http://www.cjnews.com/news/canada/netanel-ouanounou-dies-six-months-lifesupport.

McGillivray, K. (2018). Judge declines to rule in case on Ontario's definition of death. Retrieved from https://www.cbc.ca/news/canada/toronto/shalom-ouanounou-case-moot-decision-1.4904343.

Morioka, M. (2001). Reconsidering brain death: A lesson from Japan's fifteen years of experience. Hastings Center Report, 31(4), 41-46.

Network., N. Y. C. H. a. H. C. E. Brain death and reasonable accommodation. New York City Health and Hospitals Corporation.

New York State Department of Health, \& New York Task Force on Life and the Law. (2011). Guidelines for determining brain death.

Olick, R. S., Braun, E. A., \& Potash, J. (2009). Accommodating religious and moral objections to neurological death. The Journal of Clinical Ethics, 20(2), 183-191.

Racine, E. (2015). Revisiting the persisting tension between expert and lay views about brain death and death determination: A proposal inspired by pragmatism. Journal of Bioethical Inquiry, 12(4), 623631. https://doi.org/10.1007/s11673-015-9666-0.

Reifman, D. (2011). The brain death debate: A methodological analysis_Part 1 (Yoma Passage) by Daniel Reifman. Text and Texture. Retrieved from http://text.rcarabbis.org/the-brain-death-debate-amethodological-analysis-part-1-yoma-passage-by-daniel-reifman/.

Rieti, J. (2018). Ontario judge refuses family's plea to keep brain dead woman on life-support. $C B C$ News. Retrieved from https://www.cbc.ca/news/canada/toronto/taquisha-mckitty-decision-1.46743 67.

Schiff, N. D., \& Fins, J. J. (2016). Brain death and disorders of consciousness. Current Biology, 26(13), R572-R576. https://doi.org/10.1016/j.cub.2016.02.027.

Segal, E. (2014). Religious objections to brain death. Journal of Critical Care, 29(5), 875-877. https:// doi.org/10.1016/j.jcrc.2014.06.017.

Steinberg, A. (2010). The [Knesset] law of brain-respiratory death-The opinion of Rav Ovadiah Yosef. Assia, 22(3-4), 77-78.

Steinberg, A., \& Hersch, M. (1995). Decapitation of a pregnant sheep: A contribution to the brain death controversy. Transplantation Proceedings, 27(2), 1886-1887.

Wijdicks, E. F., Varelas, P. N., Gronseth, G. S., Greer, D. M., \& American Academy of Neurology. (2010). Evidence-based guideline update: Determining brain death in adults: Report of the quality standards subcommittee of the American Academy of Neurology. Neurology, 74(23), 1911-1918. https://doi.org/10.1212/WNL.0b013e3181e242a8.

Publisher's Note Springer Nature remains neutral with regard to jurisdictional claims in published maps and institutional affiliations. 